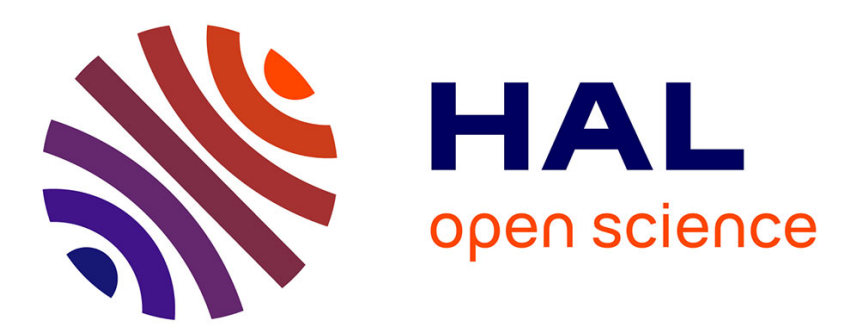

\title{
Metallurgical and mechanical analysis from thixoforging steel shape
}

\author{
Eric Becker, Régis Bigot, Laurent Langlois, Véronique Favier, \\ Jean-Christophe Pierret, Pierre Cezard
}

\section{> To cite this version:}

Eric Becker, Régis Bigot, Laurent Langlois, Véronique Favier, Jean-Christophe Pierret, et al.. Metallurgical and mechanical analysis from thixoforging steel shape. International Journal of Material Forming, 2008, pp.977-980. 10.1007/s12289-008-0221-y · hal-00781855

\section{HAL Id: hal-00781855 https://hal.science/hal-00781855}

Submitted on 29 Jan 2013

HAL is a multi-disciplinary open access archive for the deposit and dissemination of scientific research documents, whether they are published or not. The documents may come from teaching and research institutions in France or abroad, or from public or private research centers.
L'archive ouverte pluridisciplinaire HAL, est destinée au dépôt et à la diffusion de documents scientifiques de niveau recherche, publiés ou non, émanant des établissements d'enseignement et de recherche français ou étrangers, des laboratoires publics ou privés. 


\title{
Metallurgical and mechanical analysis from thixoforging steel shape
}

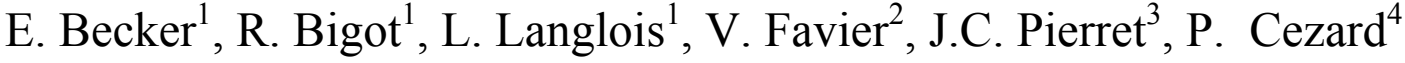 \\ ${ }^{1}$ Laboratoire de Génie Industriel et de Production Mécanique $\square$ ENSAM-4, rue Fresnel, F-57070 METZ FRANCE \\ e-mail:eric.becker@metz.ensam.fr $\square$ regis.bigot@metz.ensam.fr $\square$ laurent.langlois@metz.ensam.fr
}
${ }^{2}$ Laboratoire d ingénerie des Matériaux UMR8006 ENSAM- 151,b. de l Höpital, F-75013 PARIS FRANCE e-mail: véronique.favier@paris.ensam.fr
${ }^{3} U L G \square$ PiMW (B56), University of Liège bd de Colonster, $4 \square B-4000$ LIEGE BELGIQUE e-mail:jc.pierret@ulg.ac.be
${ }^{4}$ ASCOMETAL CREAS - avenue France, F- 57300 HAGONDANGE FRANCE e-mail:p.cezard@ascometal.lucchini.com

\begin{abstract}
Since always, Industry minimizes manufacturing process plan and increases mechanical behaviour. In this topic, the thixoforging process offers important perspectives especially steel thixoforging. It is on the way of industrial development between casting and forging process.

Previous works have illustrated the importance many parameters such as steel grade, slide speed, slug and tool temperature on the geometry from thixoforging part and of the forming load.

This paper completes the previous results. It presents an analysis from mechanical resistance of samples extracted of from thixo-extrusion parts on a high speed hydraulic press. This strength investigation is correlated with metallurgical analysis. Macrograph analyses allow identifying the material yield during the process and the different phases.
\end{abstract}

Key words: mechanical behaviour, macrostructure, microstructure, steel thixoforging, semi-solid.

\section{INTRODUCTION}

Thixoforming and rheoforming are two forming processes lately developed. It enables the forging of parts with complex shapes and gives high mechanical properties. The aim is to get a mix of casting and forging strong points. Both of thixoforging and rheoforging are based on the semisolid state, the first using the melting of the metal, the second one using the solidification of the melted steel $[1,2]$.

This document shows the progress of studies dealing with the $\mathrm{C} 38$ forming by thixoforging, conducted in ENSAM Metz $[3,4]$. The first part deals with steel thixoforging specificities and parameters affecting the forming process. The second part shows the analysis of the thermal exchange impact on the yield during the forming and on different aspects of the final part.

\section{STEEL THIXOFORGING}

The difficulty of the steel forming is mainly due the high level of temperature $\left(1400^{\circ} \mathrm{C}\right)$ and then to the die design. Studies conducted in ENSAM Metz dealt with the modelling of semi-solid steel behaviour with an original micro-macro approach $[2,5,6]$. Studies about the die design and the semi-solid state of slug are shown. Results about impact of some key parameters on thixoforging are then developed.

\subsection{Dies}

Direct extrusion test is used in order to identify key parameters concerning the yield of semi-solid steel. It consists in a diameter reduction from $40 \mathrm{~mm}$ to $12 \mathrm{~mm}$. (figure 1 ).

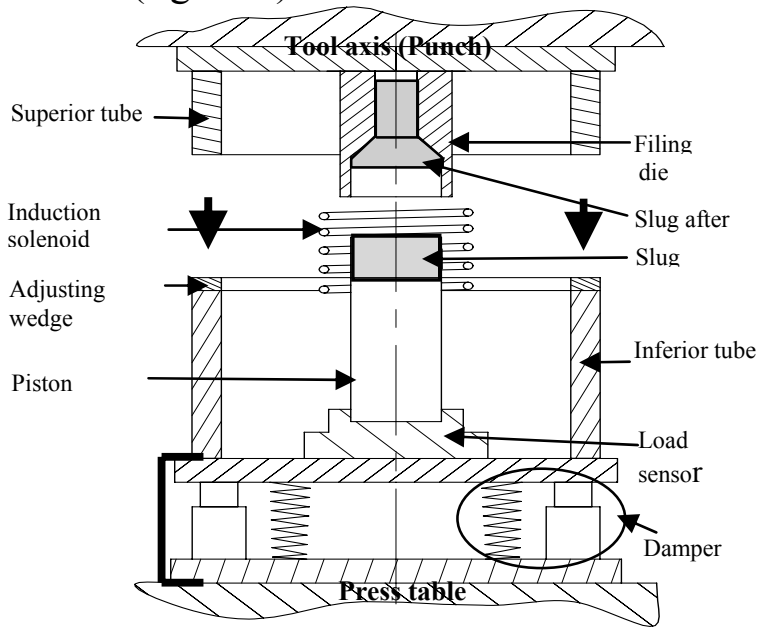

Fig. 1. Complete extrusion device mounted on the press

Dies are either at room temperature or heated at 
$400^{\circ} \mathrm{C}$ with induction heater integrated into the tool, in order to control the tests conditions and to avoid high thermal losses.

The upper die stop is not instantaneous because of the inertia, then the metal is still being deformed while the speed decrease $\left(\mathrm{v}_{\mathrm{MAX}}=1 \mathrm{~m} / \mathrm{s}\right)$. In order to avoid this phenomenon, a shock absorption system (damper) has been placed into the tool. The figure 1 shows the setting used during the tests. This tool is instrumented with load and displacement sensors.

\subsection{Slug and heating process}

Only works about C38 steel are exposed in this study. Works of Carole Rouff [5] and Pierre Cézard [7] show that the induction heating of rolled steels allows its forming by thixoforging.

Table1. Chemical composition from C38 (10-3\%) Steel

\begin{tabular}{cccccccccc}
$\mathbf{C}$ & $\mathbf{M n}$ & $\mathbf{P}$ & $\mathbf{S}$ & $\mathbf{S i}$ & $\mathbf{A l}$ & $\mathbf{N}$ & $\mathbf{N i}$ & $\mathbf{C r}$ & $\mathbf{C u}$ \\
\hline 418 & 751 & 10 & 21 & 198 & 21 & 65 & 77 & 144 & 133 \\
\hline
\end{tabular}

The choice of a steel grade for its semi-solid forming is essential. Indeed, it determines the temperature of forming and its ability to be formed at semi-solid state.

\subsection{Parameters affecting the forming process}

After a number of tests had been done on that grade, it results that the forming speed, the slug temperature and the dies temperature have major influence on the flow type of steel and the load. Table 2 illustrates the influence of these parameters $[3,4]$.

Table2. Influence of speed, slug temperature and die temperature on steel thixoforging characteristics

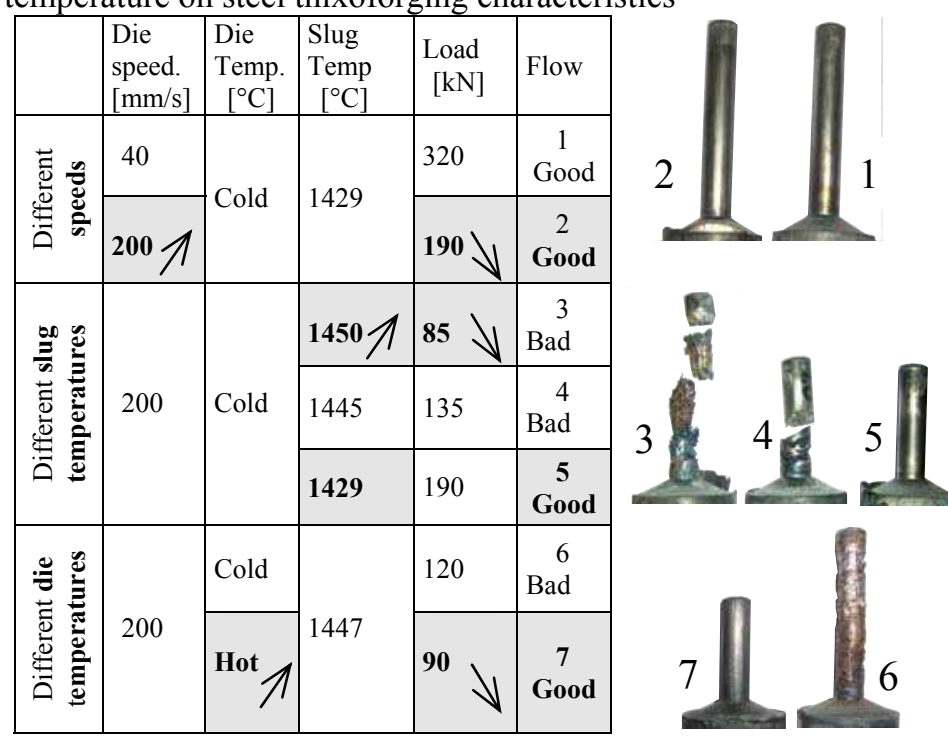

These parameters interact mainly on thermal exchanges between slug and die and between slug heart and skin, that has effects on the liquid ratio, then on the viscosity and the consistency, on the dispersion, on the load, on the yield type, on the microstructure and on the mechanical properties.

\section{IMPACTS OF THERMAL EXCHANGE}

Extrusion tests might be analysed with a crossing approach combining values of mechanical properties (HV, $R_{p}, R_{m}$, et $A \%$ ) on final parts.

\subsection{Illustration of thermal exchange by a numerical approach}

For instance, the figure 2 illustrates the influence of extrusion speed on the thermal exchange get by numerical simulations with FORGE 2005® software, the other parameters being constant.

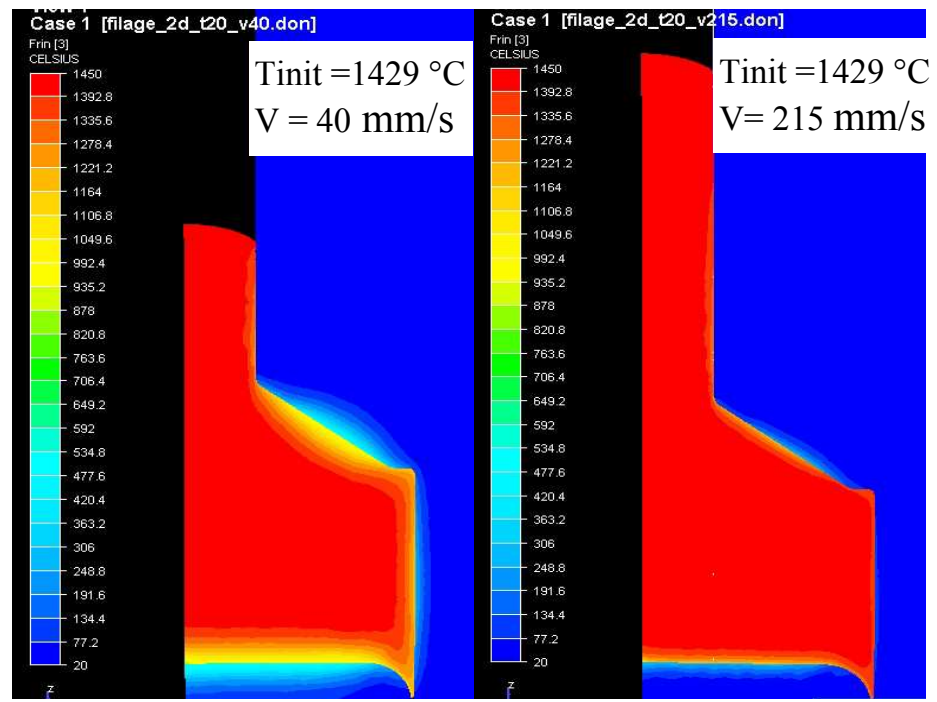

Fig. 2. Complete extrusion device mounted on the press, two examples at different die velocities

\subsection{Macroscopic analysis of the thermal affected zone.}

Figure 3 illustrates the macrographs of two samples forged in different condition of thermal exchange (minimal or maximal speed, initial slug temperature, die temperature). It $\$$ possible to distinguish three areas on each sample.

For the extrusion specimen in high thermal exchange conditions, area A illustrates a weak flow rate; the material stays in contact with the dies and is cooled quickly. A part of the metal is wrapped by the area B and $\mathrm{C}$ of the slug and enter then in the cone. During the forming process, area $\mathrm{B}$ contains a amount of semi-solid metal that is useful to feed the whole shape. Area $\mathrm{C}$ illustrates the axial flow. 


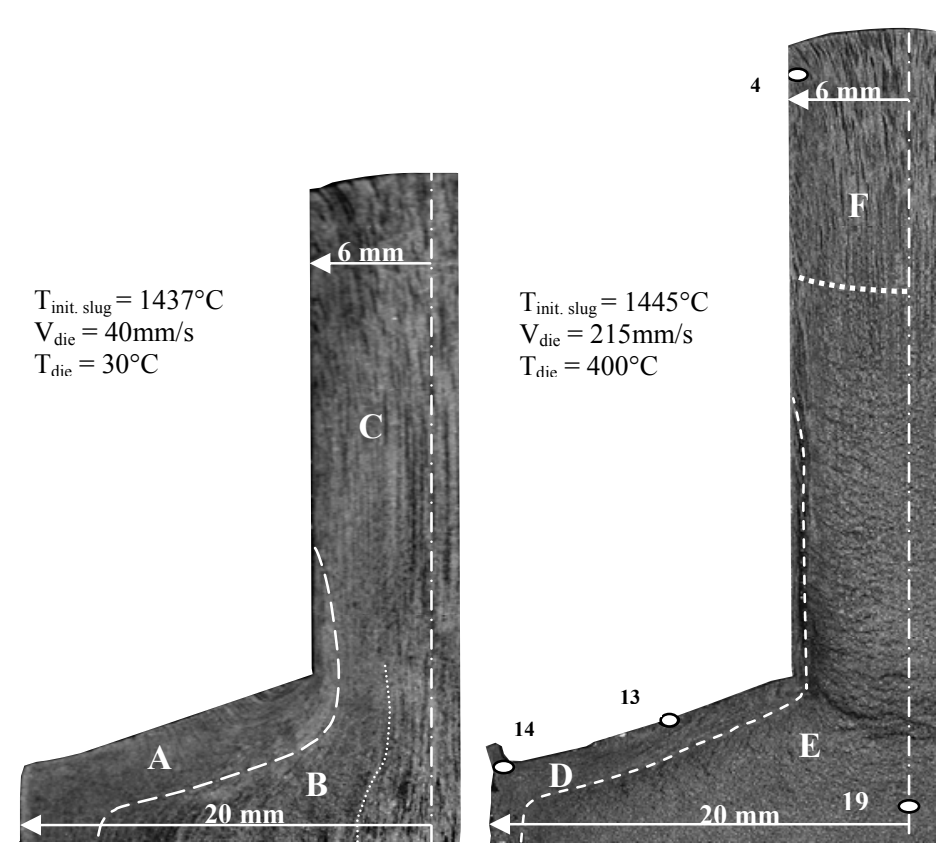

Fig. 3. Macrostructure : display from heat flux effect between the die and the shape of the flow from C38 steel

For the extrusion specimen in low thermal exchange conditions, area D is identical to area $\mathrm{A}$, except its thickness is lower. Metal from area $\mathrm{E}$ forms waves during the yield, material is semi-solid during the whole forming process. Area $\mathrm{F}$ illustrates an axial flow on a part of the extruded area.

The different thickness between area A and D corresponds to a much more important and deeper solidification due to a high level of thermal exchange between die and slug, also visible on figure 2. Some high thermal exchanges exist too in area $\mathrm{F}$ and at the end of area $\mathrm{C}$, they explain this typical forging yield. Then, a high gradient is created between the inside and outside of the part, leading to a semi-solid heart during the whole forming process. Area E keeps its semi-solid properties thanks to the areas $\mathrm{D}$ and $\mathrm{F}$, being the thermal shields by limiting the heat transfer with the die.

\subsection{Impact of thermal exchanges on local mechanical properties}

\section{3.a Hardness and micrographs}

Extruded parts hardness is analysed by Vickers hardness tests under a $3 \mathrm{~kg}$ load. Figure 4 shows a sum up of experimental hardness results. Table 3 illustrates micrographs associated with specimens 9 and 10 of figure 4 . In table 3 we made some comments with Handbook reference [8], however experiments data can not be the identical. These comments give some indications to lecturers with thixotropic micrographs.

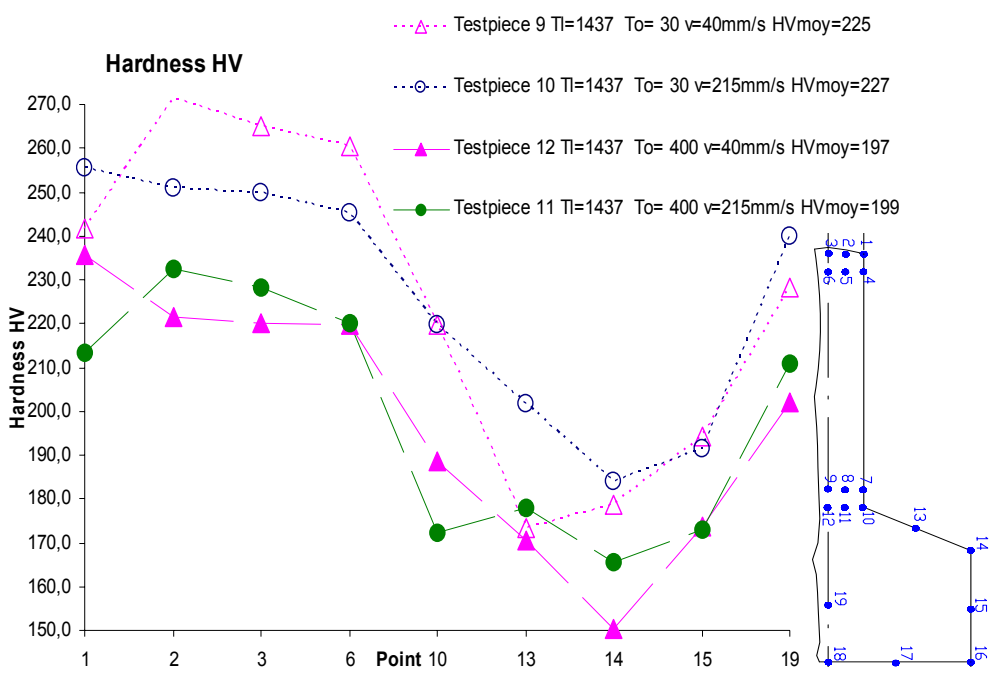

Fig. 4. Vickers Hardness (weight $3 \mathrm{~kg}$, steel C38, $T_{\text {slug }}=1437^{\circ} \mathrm{C}$ )

The Vickers hardness reduction at the points 13 and 14 illustrates a low cooling speed after the forming (the cooling is made into the dies) or a chemical gradient of the slug. Micrographs confirm by high ferrite grade of decarburized area, that it is not very sensitive to the cooling speed.

The variation of the Vickers hardness is less important when the forming speed is higher. Figure 4 compares hardness of parts forged with heated dies $\left(400^{\circ} \mathrm{C}\right)$ and those with room temperature dies. Vickers hardness is less important when the dies are heated; it can be explained by a thermal exchange between slug and dies lower. Points 13 and 14 have the lowest hardness, microstructures show a decarburized area already observed before. Point 19, at the heart of the sample, has an important grain size, independently of the tool temperature. This can be explained by a high temperature with a long keeping time during the forming process.

Table3. Microstructures show the impact from forming speed

\begin{tabular}{|c|c|c|}
\hline Points & $\begin{array}{ll}\text { Testpiece } 9 & \mathrm{~T}_{\text {slug }}=1437^{\circ} \mathrm{C} \\
\mathrm{T}_{\text {die }}=30^{\circ} \mathrm{C} & \mathrm{V}_{\underline{\text { die }}}=40 \mathrm{~mm} / \mathrm{s}\end{array}$ & $\begin{array}{ll}\text { Testpiece } 10 & \mathrm{~T}_{\text {slug }}=1437^{\circ} \mathrm{C} \\
\mathrm{T}_{\underline{\text { die }}}=30^{\circ} \mathrm{C} & \mathrm{V}_{\text {die }}=215 \mathrm{~mm} / \mathrm{s}\end{array}$ \\
\hline 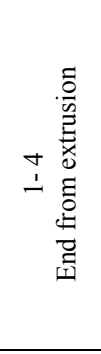 & $\begin{array}{l}\text { Structure consists of envelopes of } \\
\text { proeutectoid ferrite (light) with } \\
\text { emerging spines of ferrite, in a } \\
\text { matrix of pearlite (grey) ([8] fig. } \\
132 \text { page 188). } \mathrm{HV}=237\end{array}$ & $\begin{array}{l}\text { Ferrite (light) at prior austenite } \\
\text { grain boundaries and plates within } \\
\text { grains in a matrix of pearlite } \\
\text { (grey) ([8] fig. } 19 \text { page 213) } \\
\mathrm{HV}=255\end{array}$ \\
\hline 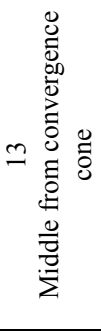 & $\begin{array}{l}\text { Surface shows decarburization. } \\
\text { The light areas near bottom of } \\
\text { micrograph are ferrite; the matrix } \\
\text { is pearlite (grey) ([8] fig. } 18 \text { page } \\
\text { 213) } \mathrm{HV}=173\end{array}$ & $\begin{array}{l}\text { Ferrite (light) at prior austenite } \\
\text { grain boundaries and plates within } \\
\text { grains in a matrix of pearlite (grey } \\
\text { ([8] fig. } 19 \text { page 213) HV=201 }\end{array}$ \\
\hline
\end{tabular}




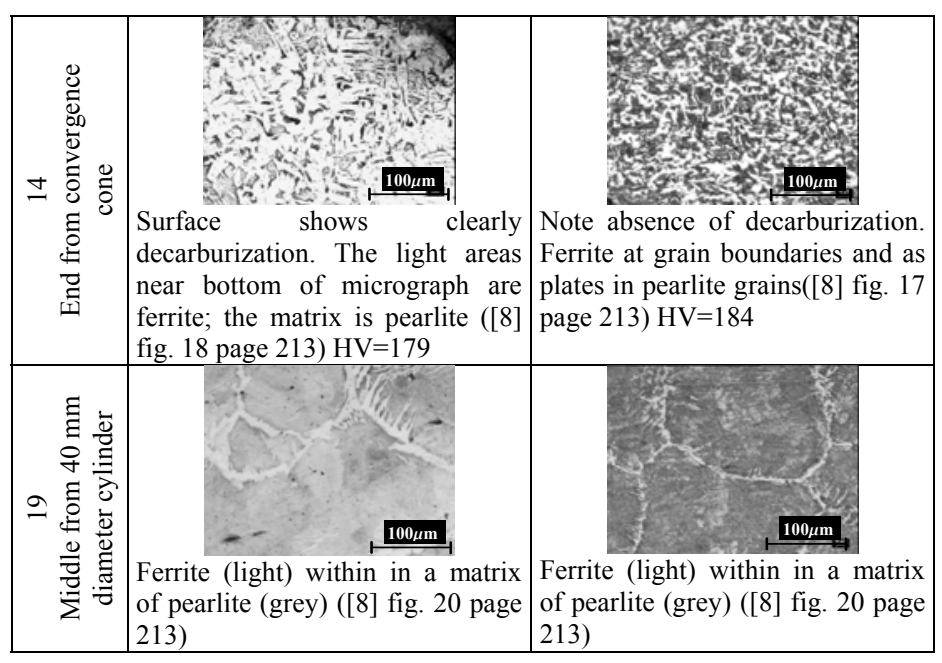

3.3.b Elasticity, strength and elongation

Elasticity limit, strength and elongation are determined by tensile tests. Table 4 shows a synthesis of the results obtained on groups of three specimens sampled among thixoforged extruded parts in different conditions of speed, die temperature and slug temperature.

Elasticity limit and strength are quite constant while forming speed varies (max. $6 \%$ for $\mathrm{Rp}$ and max. $2,3 \%$ for $\mathrm{Rm}$ ), though they decrease when dies temperature increases (min. $10 \%$ for $\mathrm{Rp}$ and $\mathrm{min}$. $4,4 \%$ for $\mathrm{Rm}$ ), which is normal for a high variation of the thermal gradient (die $\square$ part) during the forming process and for high temperature level for heated dies.

Elongation increases when $\mathrm{Rm}$ and $\mathrm{Rp}$ decrease, which is normal too except for the last values $\left(\mathrm{v}=200 \mathrm{~mm} / \mathrm{s}\right.$ and $\left.\mathrm{To}=400^{\circ} \mathrm{C}\right)$.

Table4. Influence from different thixoforging parameter of C38 steel mechanical characteristic

\begin{tabular}{|c|c|c|c|c|c|}
\hline $\begin{array}{c}\text { Speed } \\
{[\mathrm{mm} / \mathrm{s}]}\end{array}$ & $\begin{array}{c}\mathrm{T}^{\circ}{ }_{\text {die }} / \\
\left.\mathrm{T}^{\circ}{ }_{\text {slug }}{ }^{\circ} \mathrm{C}\right]\end{array}$ & $\begin{array}{c}\mathrm{Rp} 0,2 * \\
{\left[\mathrm{~N} / \mathrm{mm}^{2}\right]}\end{array}$ & $\begin{array}{c}\mathrm{Rm}^{*} \\
{\left[\mathrm{~N} / \mathrm{mm}^{2}\right]}\end{array}$ & $\mathrm{Rp} / \mathrm{Rm}$ & $\mathrm{A} \%$ \\
\hline $\mathbf{5 0}$ & $\mathbf{3 0 / 1 4 2 0}$ & $\mathbf{5 3 7}$ & $\mathbf{8 1 8}$ & 0,66 & 18,9 \\
\hline $\mathbf{5 0}$ & $\mathbf{4 0 0 / 1 4 2 9}$ & 457 & 756 & 0,60 & $\mathbf{2 1 , 0}$ \\
\hline $\mathbf{2 0 0}$ & $\mathbf{3 0 / 1 4 2 0}$ & 504 & 800 & 0,63 & 20,7 \\
\hline $\mathbf{2 0 0}$ & $\mathbf{4 0 0 / 1 4 2 9}$ & 458 & 765 & 0,60 & $\mathbf{1 6 , 0}$ \\
\hline \multicolumn{2}{|c|}{$\begin{array}{l}\text { Steel data } \\
\text { from C38 }\end{array}$} & $\mathbf{2 4 3 0}$ & $\begin{array}{c}650 \text { to } \\
800\end{array}$ & & $\geq \mathbf{1 6}$ \\
\hline
\end{tabular}

Characteristics are the same as the native state of the steel.

\section{CONCLUSIONS}

These results illustrate the important impact of initial slug temperature, forming speed and dies temperature on thermal exchanges during a forming process with $\mathrm{C} 38$ steel at semi-solid state. These parameters have also an impact on the final part shape. Thermal exchanges have to be limited and controlled in order to keep a constant and homogenous liquid/solid ratio during the whole operation. A compromise between speed and temperature can be found to have a homogenous yield, a low load and high mechanical properties. Ability to the thixoforging can be defined in a zone based on the steel grade.

During a thixoforging operation, forming speed has effects on thermal exchanges, but also on the solid lattice dispersion, which is pointed in several studies [9].

This work combined to the previous researches confirms that tool design with close dies for thixoforging is quite similar to net-shape forging.

From a forged product point of view, experimental results lead to a new design of parts from functional specifications. This design approach is based on predictive tools such as behaviour laws developed and implemented with dedicated software such as Forge2005® $[7,10]$.

\section{ACKNOWLEDGEMENTS}

Authors would like to thank Mr. Ahmed RASSILI, president of the action COST 541, who allowed us to realize additional tests on the site ULg at Liège (Belgium), Sylvio DEPAOLIS, Stéphane MATHIEU and Luc MORHAIN, for their technical support.

\section{REFERENCES}

1. Suery, M., Mise en forme des alliages métalliques à l'état semisolide. Lavoisier, Hermes Sciences, 2002. Traité MIM.

2. Atkinson, H.V., Modelling the semisolid processing of metallic alloys. Progress in Materials Science, 2005. 50(3): p. 341-412.

3. Cezard, P., et al. Thixoforming of Steel: New tools conception to analyse thermal exchanges and strain rate effects. in ESAFORM 2007. 2007, April 18th-20th. Zaragose, Spain.

4. Becker, E., et al. Influence de la vitesse de mise en forme et du cycle sur le thixoforgeage des aciers. in HSIMP. 2007, November 13th-14th. Senlis, France.

5. Rouff, C., Contribution à la caractérisation et à la modélisation du comportement d'un acier à l'état semi-solide. Application au thixoforgeage. 2003, ENSAM: Metz.

6. Favier, V., et al., Micro-macro modelling of the isothermal steadystate behaviour of semi-solids. International Journal of Forming Processes, 2004. 7: p. 177-194.

7. Cezard, P., Impact des effets thermiques sur le comportement du matériau lors de la mise en forme des aciers à l'état semi-solide : analyse expérimentale et numérique., in ENSAM Metz. 2006.

8. Handbook, A., Metallography and Microstuctures, ed. M.H. Formerly Ninth Edition. Vol. 9. 1998.

9. Cezard, P., et al. Micro-macro modelling of the steady-state semisolid behaviour and finite element simulation. in 8th Semi-solid Processing of alloys and composites. 2004, September. Chypre.

10. Cezard, P., et al., Simulation of semi-solid thixoforging using a micro-macro constitutive equation. Computational Materials Science, 2005. 32: p. 323-328. 